\title{
RESPOSTAS DE UM SOLO RESIDUAL DA FORMAÇÃO GUABIROTUBA-PR À INTERAÇÃO COM SOLUÇÕES CONTAMINANTES
}

KATIANORMA SIEDLECKI

\author{
DISSERTAÇÃO DE MESTRADO - Programa de Pós-Graduação em Geologia - UFPR \\ DATA DE DEFESA: 23/11/98
}

A malha urbana, configurada pela grande Curitiba, tem limites praticamente coincidentes com a distribuição geográfica dos sedimentos da Bacia de Curitiba. A inexistência de informações sobre o lançamento de efluentes industriais no meio, alarma e reclama urgentemente por estudos de compatibilidade entre lixívias e materiais que compõem a Bacia de Curitiba: sedimentos pleistocênicos da Formação Guabirotuba e depósitos aluvionares holocênicos. Em sua parte teórica, este trabalho ocupa-se das variáveis relacionadas à interação solo-solução contaminante, explorando sobretudo as propriedades dos argilo-minerais como constituintes do solo que desempenham importante papel na dinâmica de trocas de cátions. O estudo aplicado centra atenção na caracterização geotécnica e físico-química de solos residuais da Formação Guabirotuba, explorando técnicas laboratoriais consagradas, com adequação aos chamados "ensaios de compatibilidade". O emprego de soluções fortemente enriquecidas em elementos pesados (Cu e Zn), simulando padrões de emissões industriais, permitiu a observação de importantes efeitos no comportamento geotécnico das amostras ensaiadas. Ensaios de adsorção via Batch Tests, realizados com amostras de solo residual da Formação Guabirotuba e soluções aquosas enriquecidas em elementos pesados, revelaram resultados muito interessantes, que em essência refletem a aptidão eletroquímica dos constituintes minerais presentes, atribuindo-se sobretudo à esmectita cálcica e aos carbonatos, a responsabilidade pela imobilização dos metais pesados. Os resultados foram objeto de tratamento matemático (regressão linear por transformação), visando a definição dos parâmetros $\mathrm{Kd}, \mathrm{N}$ e R2. Ensaios de tamponamento, simples rotinas de titulação, traduziram a capacidade do material da Formação Guabirotuba resistir ao incremento de condições ácidas, evidenciando sua superior performance em relação à amostra caulinítica também tratada. 